\title{
New blood pressure levels in Peruvian high altitude populations and the new North American high blood pressure guidelines
}

\begin{abstract}
The publication of the new American Heart Association High Blood Pressure Guidelines, presented by the American Heart Association and the American College of Cardiology, has caused great controversy; some physicians support them out of respect and recognition to the scientists who developed the guidelines while others are extremely critical. Higher blood pressure equals more cardiovascular risk, lower prevalence in the population and lower distribution between hypertensive subjects. Any therapeutic proposal to decrease blood pressure will result in decreasing cardiovascular risks. For now, we must use 140/90mm Hg in the Peruvian Coast and Amazon Rainforest, and its recently determined equivalent 134/89mm Hg for chronic adult residents of the Andean Highlands.
\end{abstract}

Keywords: hypertension, American guidelines, cardiovascular risk, peru, high altitude
Volume 12 Issue 4 - 2019

\author{
Luis Segura Vega \\ Department of Cardiology, Cayetano Heredia Peruvian \\ University, Peru
}

\begin{abstract}
Correspondence: Luis Segura Vega, Cardiologist, Professor of Medicine at Cayetano Heredia Peruvian University, Peru,
\end{abstract} Email seguis07@gmail.com

Received: May 17, 2019 | Published: July 31, 2019

\section{Introduction}

The diagnosis of hypertension in adults is based on figures higher than conventional values of $140 / 90 \mathrm{~mm} \mathrm{Hg}$ until now, for any age or sex, without taking into account geographical or ethnic variations. For children and adolescents, the situation is different due to the biological changes that occur in this phase of human growth. To determine normal blood pressure in children, it is necessary to use percentile tables according to age, sex and height; however, in the adolescent population, it is very complex to determine the values of normal blood pressure, not only because of the deep physiological, physical and social changes, but also because of the influence of ethnic and geographical variability. Therefore, studies to determine normal blood pressure in adolescents are valid only for the locality investigated, ${ }^{1-3}$ concepts that must be taken into account to avoid over diagnosis of hypertension in young people. In our country, Peru, the established universal criteria cannot be applied to all its inhabitants, as a consequence of the geographical, ethnic, biological, phenotypic and genotypic variations that differentiate our Andean populations; one example of this is the range of blood pressure of $140 / 90 \mathrm{~mm} \mathrm{Hg}$ as normal in people who live chronically in the Andean Highlands to limit hypertension. As a result of this problem we have carried out a study, presented at the XXV Peruvian Congress of Cardiology and soon to be published, of which a summary of some concepts is presented below.

In Peru, a country so diverse and millennial, we have populations located in the Andes Mountains that have biological and genetic characteristics very different from those established at sea level. Hypobaric hypoxia is evidently the most important cause of the difference between these two populations; the inhabitants of the Andean Highlands live subjected to an essentially hypoxic environment. Their organism has been in continuous adaptation for approximately 20 thousand years, successfully developing specific genetic changes, physiological and anatomical, to live naturally in an environment where the atmosphere contains less oxygen due to decreased barometric pressure. "Understanding that adaptation to extreme environmental conditions is important to know our genetic and cultural survival," says Kurt Rademaker of the University of Maine. The studies carried out in the native Andean populations, and compared with those made to natives of the sea level, have found significant differences in their physiological values and in the pathologies they suffer. For these differentiations, reference values of normality have been used that correspond to the inhabitants at sea level, which are not applicable to the inhabitants of the Andean Highlands. In these comparative studies, it has been shown for example, that natives of the Highlands have low blood glucose levels because their extrahepatic tissues are more efficient to use glucose; on the other hand, diabetes is 'less prevalent' in them. ${ }^{4}$ Those born and developed in the Highlands acquire a larger residual lung volume, especially if they are of Quechua or Aymara origin, as an expression of genetic adaptation to hypoxia; this increased residual volume also contributes to a satisfactory cardiovascular adaptation. ${ }^{5}$ There are works done by different researchers of the country and abroad about the metabolism of the natives of the Highlands, trying to explain the differences related to the natives at sea level; Gustavo F. Gonzales did a good review of more than eighty works on the subject. ${ }^{6}$ Another example is the work of Daniel Yumpo Castañeda, on the measurement of arterial gases in people considered healthy in Huancayo, a city at 3 273 meters above sea level, where he concludes that the normal values for natives at sea level are not valid for natives of the Highlands. Thus, for example, he says that the high levels of $\mathrm{pH}$ in Huancayo would suggest, according to the values used in the Coast, that said population lives in a chronic respiratory alkalosis, an incorrect assessment because these inhabitants maintain an adequate acid base equilibrium; He concludes that it is necessary to have reference values of normality for the inhabitants of Highlands. ${ }^{7}{ }^{8}$ With the epidemiological studies "Risk Factors of Cardiovascular Diseases in Peru", TORNASOL I and II, performed at national level, using as normal pattern 140/90 $\mathrm{mm} \mathrm{Hg}$, it was shown that in five years the prevalence of hypertension was increased significantly in all the studied populations, from $23.7 \%$ to $27.3 \%$ at national level, $27.3 \%$ to $31.6 \%$ in the Coast, $20.4 \%$ to $23.2 \%$ in the Highlands (or Andean region), and $22.7 \%$ to $26.6 \%$ 
in the Rainforest. As can be seen, the prevalence of hypertension is significantly lower in the Highlands than in the other two natural regions..$^{-1}$

Considering that the Andean populations have very different characteristics from those at sea level, the purpose of our work was to find the normal pattern of blood pressure in the permanent inhabitant of the Highlands, applying percentiles equivalent to the standard values of 140/90mm $\mathrm{Hg}$, universally used for blood pressure. And the result was that the equivalent corresponded to $134 / 89 \mathrm{~mm} \mathrm{Hg}$, that is, the normal pattern of blood pressure in the Andean adult. This calculation was obtained using a sample of 12 448people, older than 18years old, normotensive, from the TORNASOL I and II studies, ruling out compensated hypertensive subjects and pregnant women. If we consider $134 / 89 \mathrm{~mm} \mathrm{Hg}$ as the normal pattern for the Andean inhabitant and this value is used to reassess the prevalence of hypertension in this population, we see a significant increase from $23.2 \%$ (according to $140 / 90 \mathrm{~mm} \mathrm{Hg}$ ) to $27.2 \%$; with this figure matches the national prevalence of hypertension, $27.3 \%$. The prevalence of isolated systolic hypertension and mixed hypertension also increases in these calculations, while the prevalence of isolated

Table I classification of blood pressure in the highlands, adapted to the European classification for 140/90mm hg. Tornasol II

\begin{tabular}{lllllll}
\hline \multicolumn{2}{l}{ Modified Classification, TORNASOL II } & \multicolumn{2}{l}{ Prevalence in the Highlands } & \multicolumn{2}{c}{ Distribution } \\
\hline Category & SBP & DBP & $\%$ & $\%$ & $\%$ & $\%$ \\
Optimal & $<120$ & $<80$ & 46.5 & 82.2 & - & - \\
Normal & $120-129$ & $80-84$ & 27.5 & & - & - \\
High Normal & $130-139$ & $85-89$ & 8.2 & & - & - \\
Isolated Diastolic H. & $<140$ & $>=90$ & 12.7 & 12.7 & 71.6 & 71.6 \\
Grade I Mixed H. & $140-159$ & $90-99$ & 1.4 & 3.1 & 7.6 & 17.6 \\
Grade II Mixed H. & $160-179$ & $100-109$ & 1 & & 5.6 & \\
Grade III Mixed H. & $>=180$ & $>=110$ & 8 & & 4.4 & 10.8 \\
Isolated Systolic H. & $>=140$ & $<90$ & 1.9 & 1.9 & 10.8 \\
\hline
\end{tabular}

SBP, systolic blood pressure; DBP, diastolic blood pressure; $\mathrm{H}$, Hypertension

Table 2 classification of blood pressure in the highlands adapted to the European classification for $134 / 89 \mathrm{~mm}$ hg

\begin{tabular}{|c|c|c|c|c|c|c|}
\hline \multicolumn{3}{|c|}{ Modified Classification, TORNASOL II } & \multicolumn{2}{|c|}{$\begin{array}{l}\text { Prevalence in the } \\
\text { Highlands }\end{array}$} & \multicolumn{2}{|c|}{ Distribution } \\
\hline Category & SBP & DBP & $\%$ & $\%$ & $\%$ & $\%$ \\
\hline Optimal & $<114$ & $<78$ & 41.5 & 81.3 & - & - \\
\hline Normal & $114-123$ & $78-83$ & 28.7 & & - & - \\
\hline High Normal & $124-133$ & $84-88$ & II & & - & - \\
\hline Isolated Diastolic H. & $<134$ & $>=89$ & 11.8 & 11.8 & 63.3 & 63.3 \\
\hline Grade I Mixed H. & $|34-15|$ & 89-99 & 2 & 4.1 & 10.4 & 21.9 \\
\hline Grade II Mixed H. & $>=152$ & $100-105$ & 1.5 & & 8 & \\
\hline Grade III Mixed H. & - & $>=106$ & 0.7 & & 3.5 & \\
\hline Isolated Systolic H. & $>=134$ & $<89$ & 2.8 & 2.8 & 14.8 & 14.8 \\
\hline
\end{tabular}

SBP, systolic blood pressure; DBP, diastolic blood pressure; $\mathrm{H}$, Hypertension

diastolic hypertension and that of normotensive hypertension decreases significantly.

In the literature of the Andean countries hypertension is considered in the Highlands as lower risk factor for stroke, due to the "lower eant levels of prevalence", and rather refers to hypoxia and polycythemia as their major risk factors. It is known that the prevalence of stroke is similar in the populations at sea level and in the Highlands. ${ }^{12}$ normal range for the inhabitant of the Highlands, the prevalence of hypertension in altitude populations is as high as in those at sea level, stroke. The goals for the treatment of hypertension in high-altitude populations should be less than 134/89mm Hg. There are about 442 000 people living in the Highlands considered "non-hypertensive" who wander without any treatment. Adapting our figures of Andean the European classification, the changes in the values of prevalence and distribution of hypertension according to the universal pattern 140/90mm $\mathrm{Hg}$ and the Andean 134/89mm Hg are shown in Tables $1 \& 2$. 
Figure 1 shows the prevalence of hypertension at national leve according to the $140 / 90 \mathrm{~mm} \mathrm{Hg}$ range, where the female curve is lower until 50 years old while after 55 surpasses the male curve. Figure 2 shows the prevalence of hypertension in the Andean inhabitant according to age and sex, comparing blood pressure patterns $140 / 90 \mathrm{~mm} \mathrm{Hg}$ and $134 / 89 \mathrm{~mm} \mathrm{Hg}$. In women, the prevalence, according to the universal pattern $140 / 90 \mathrm{~mm} \mathrm{Hg}$ is lower than in men until the age of 50 years; Then, at 65 , the female curve surpasses the male curve, as it does everywhere in the world. With $134 / 89 \mathrm{~mm} \mathrm{Hg}$, the differences are greater between both genders; the prevalence of hypertension in women is always lower than in men, and there is an approach towards 50 and 65 years of age, but without reaching men.

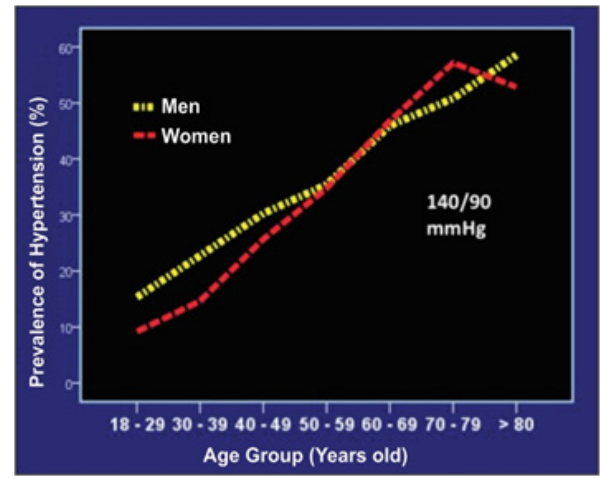

Figure I National blood hypertension by age and sex.
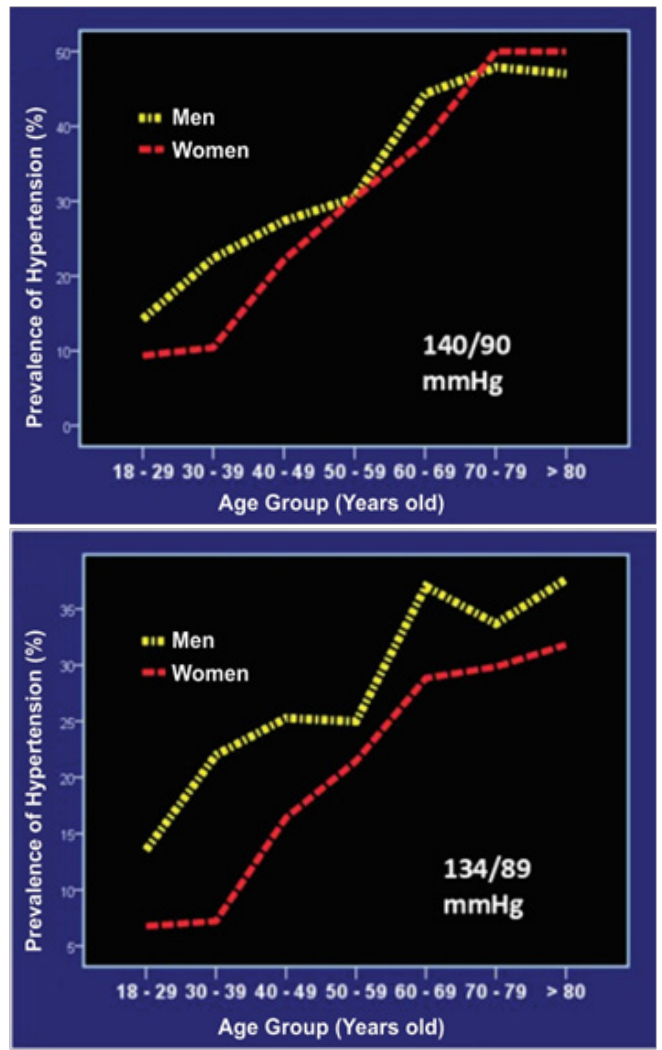

Figure 2 Blood hypertension in the highlands by age and sex.

Finally, a commentary on the new American Guidelines for Hypertension, presented in a joint session by the American Heart Association (AHA) and the American College of Cardiology (ACC), on November $14,2017,{ }^{13}$ which has caused a tremendous controversy worldwide. According to these guidelines, those with a blood pressure of $130 / 80 \mathrm{~mm} \mathrm{Hg}$ or more are considered hypertensive, compared to the previous criterion $140 / 90 \mathrm{~mm} \mathrm{Hg}$.

This was the classification of the 2017 ACC/AHA guide compared with the previous guide $\mathrm{JNC} 7$ (Table 3). The problem is that these guidelines are very much based on the SPRINT study,${ }^{14}$ which recruited people over 50years of age, non-diabetic, with one or more cardiovascular risk factors and systolic blood pressure of 130 to 180 $\mathrm{mm} \mathrm{Hg}$. They were assigned to a group with the goal of lowering the blood pressure to less than $140 \mathrm{mmHg}$, without exceeding $130 \mathrm{mmHg}$, with a 'standard' hypotensive treatment; and to another group with 'intensive' treatment at a blood pressure lower than $120 \mathrm{~mm} \mathrm{Hg}$. In the latter group, the fatal and non-fatal cardiovascular events were minor, but with a significantly higher frequency of adverse events attributable to the medication: hypotension, syncope, electrolyte abnormalities, acute renal failure. The SPRINT study is compared with the ACCORD trial ${ }^{15}$ inevitably, because they resemble each other; both separate two groups with the same criteria, blood pressure and standard and intensive treatments. The difference is that the SPRINT excluded diabetics, the ACCORD worked with diabetics, and in their results, in the group of hypertensive patients with intensive treatment there was an excess of 54 more deaths, especially cardiovascular, which forced to suspend the study for 17 months before the scheduled date for its completion. The publication of these guidelines has caused a great controversy; some support it out of respect and recognition for the scientists who elaborated it and others are highly critical accusing them of a "lack of methodological rigor", "giving too much relevance to the SPRINT study", of "being unrelated from clinical practice", of giving an effect of "medicalization of new patients", among others.

Table 3 Comparison of the JNC 7 guideline and the 2017 acc/aha guideline

\begin{tabular}{|c|c|c|}
\hline $\begin{array}{l}\text { Systolic and Diastolic } \\
\text { Blood Pressure }(\mathrm{mm} \\
\mathrm{Hg})\end{array}$ & JNC 7 Guideline & $\begin{array}{l}2017 \mathrm{ACC} / \\
\text { AHA } \\
\text { Guideline }\end{array}$ \\
\hline$<120$ and $<80$ & Normal & Normal \\
\hline $120-129$ and $<80$ & Prehypertension & Elevated \\
\hline $130-139$ or $80-89$ & Prehypertension & $\begin{array}{l}\text { Stage I } \\
\text { Hypertension }\end{array}$ \\
\hline $140-159$ or $90-99$ & Stage I Hypertension & $\begin{array}{l}\text { Stage } 2 \\
\text { Hypertension }\end{array}$ \\
\hline$\geq 160$ or $\geq 100$ & Stage 2 Hypertension & $\begin{array}{l}\text { Stage } 3 \\
\text { Hypertension }\end{array}$ \\
\hline
\end{tabular}

Source:ACC/AHA, 2017.

At higher blood pressure, there is more cardiovascular risk, lower prevalence in the population, and lower percentage distribution among hypertensive patients (Tables 1 and 2); therefore, any therapeutic proposal to decrease blood pressure will lead to lower cardiovascular risks. I think we should stick to the prudent comments of many scientific institutions like the Spanish Society of HypertensionSpanish League for the Fight against Arterial Hypertension, ${ }^{16}$ which recommends "caution and carefully analyze the American document before making any decision regarding the usual clinical practice". The Board of Arterial Hypertension of the SAC issued a document clarifying the position of the Society: "From $\mathrm{SAC}^{17}$ we do not agree that there is sufficient evidence to reduce the levels of diagnosis and control of blood pressure below the figures from our recently 
developed consensus." For now, let us use 140/90mm Hg in our Coast and Amazon Rainforest, and its equivalent, $134 / 89 \mathrm{~mm} \mathrm{Hg}$, for chronic adult residents of our Andean Highlands."In sum, we can affirm that no criterion of normality can account for the immense biological and, particularly, psychological variability of the human being, and that there is no universal criterion of normality applicable to all individuals of all societies, and cultures and in any historical time. That is why it is rightly argued that normality is a relative concept." Dr. Alejandro Goic. "The end of Medicine", Master of Chilean Internal Medicine Award (2005).

\section{Acknowledgement}

None.

\section{Conflicts of interest}

Authors declare that there is no conflict of interest.

\section{Funding}

None.

\section{References}

1. Pàll D, Katona É, Fülesdi B, et al. Blood pressure distribution in a Hungarian adolescent population: comparison with normal values in the USA. Journal of hypertension. 2003;21(1):41-47.

2. Díaz JJ, Galán CR, Guerrero SM. Utilidad de la fórmula de Somu en el diagnóstico de hipertensión arterial en niños y adolescentes españoles. Medicina Clínica. 2003;121(20):776-778.

3. Ghanbarian A, Rezaei-Ghaleh N, Salehi P, et al. Blood pressure distribution in an Iranian adolescent population: Tehran Lipid and Glucose study. Medical Journal of Malaysia. 2006;61(4):433-437.

4. Málaga G, Zevallos-Palacios C, Lazo MDL, et al. Elevada frecuencia de dislipidemia y glucemia basal alterada en una población peruana de altura. Revista peruana de medicina experimental y salud pública. 2010;27:557561.

5. Frisancho AR. Developmental functional adaptation to high altitude. American Journal of Human Biology. 2013;25(2):151-168.

6. Gonzáles Rengifo GF. Metabolismo en las grandes alturas. Acta Andina 2001;9(1/2):31-45.
7. Yumpo D. Estudio de valores de referencia de gases arteriales en pobladores de altura. Enfermedades del Tórax. 2002;45(1):40-42.

8. Zubieta G. El Equilibrio Ácido Base y la 9. Fórmula de Tolerancia a la Altura [Video archive]. 2015.

9. Vega LSD, Regulo Agusti C, Ramírez JP. Factores de riesgo de las enfermedades cardiovasculares en el Perú. Revista Peruana de Cardiología. 2006;32(2):82-128.

10. COLS DLSV. La hipertensión arterial en el Perú según el estudio TORNASOL II. Revista Peruana de Cardiología. 2011;37(1):1-9.

11. Segura Vega L, Agusti C, Ruiz Mori E. Factores de riesgo de las enfermedades cardiovasculares en el Perú II. Estudio TORNASOL II comparado con TORNASOL I después de cinco años. Rev. peru. cardiol. (Lima). 2013;39(1):5-59.

12. Ortiz E, Ojeda O, Silva F. Accidente cerebrovascular en poblaciones situadas a grandes alturas: revisión y análisis de los factores de riesgo. Revista ecuatoriana de neurología. 2008;17(1-3):1-21.

13. Whelton PK, Carey RM, Aronow WS, et al. 2017 ACC/AHA/AAPA/ $\mathrm{ABC} / \mathrm{ACPM} / \mathrm{AGS} / \mathrm{APhA} / \mathrm{ASH} / \mathrm{ASPC} / \mathrm{NMA} / \mathrm{PCNA}$ guideline for the prevention, detection, evaluation, and management of high blood pressure in adults: a report of the American College of Cardiology/American Heart Association Task Force on Clinical Practice Guidelines. Journal of the American College of Cardiology. 2018;71(19):e127-e248.

14. SPRINT Research Group. A randomized trial of intensive versus standard blood-pressure control. New England Journal of Medicine. 2015;373(22):2103-2116.

15. ACCORD Study Group. Effects of intensive blood-pressure control in type 2 diabetes mellitus. New England Journal of Medicine. 2010;362(17):1575-1585.

16. Gijón Conde T, Gorostidi M, Camafort M, et al. Documento de la Sociedad Española de Hipertensión-Liga Española para la Lucha contra la Hipertensión Arterial (SEH-LELHA) sobre las guías ACC/AHA 2017 de hipertensión arterial. Hipertensión y riesgo vascular. 2018;35(3):119129.

17. Folgarait A. Congreso AHA: Controversia por cambios en guía de hipertensión arterial. Argentina: Sociedad Argentina de Cardiología; 2017. 